\title{
Technological growth: a Brazil-World evolution and re-adaptation after COVID-19
}

\author{
Avanço Tecnológico: evolução e readlaptação do Brasil e do mundo depois do COVID-19
}

Received: 09/14/2021 | Reviewed: 09/20/2021 | Accept: 09/23/2021| Published: 09/26/2021

\author{
Glauco Fontgalland Filho \\ ORCID: https://orcid.org/0000-0001-8523-863X \\ Federal University of Campina Grande, Brazil \\ E-mail: glauco.filho@ee.ufcg.edu.br \\ Isabel Lausanne Fontgalland \\ ORCID: https://orcid.org/0000-0002-0087-2840 \\ Federal University of Campina Grande, Brazil \\ E-mail: isabelfontgalland@gmail.com
}

\begin{abstract}
The year of 2020 became known as the year of the COVID-19 pandemic. This pandemic has been changing the socioeconomic structures of the world and the educational institutions in Brazil, halting face-to-face activities as time progressed in response to the social distancing measures. Arising from an early perspective of growth, Brazil had to take a leap of faith in readapting itself to the set conditions. According to the teaching method, technology-mediated learning has gained emphasis and makes room for distinguished human interactions. These teaching practices already existed, but only reached a small scale. Technology had to reshape its manners to comfort the demand and the new health requirements. This article presents and discusses the Brazilian perspectives on the challenges and opportunities for the use of new and readapting technologies for the evolution and survival of the pandemic. The main results imply that the enactment of digital inclusion policies seeking to reduce regional inequalities of internet access is a necessary condition for any online teaching strategy to flourish and that technological innovation is parallel to the time progression of the world's condition.
\end{abstract}

Keywords: Evolution; Internet access; Readapting technology; Technological innovation.

\begin{abstract}
Resumo
O ano de 2020 ficou conhecido como o ano da pandemia COVID-19. Essa pandemia mudou as estruturas socioeconômicas do mundo e as principais instituições educacionais no Brasil, interrompendo as atividades presenciais com o passar do tempo em resposta às medidas de distanciamento social. Saindo de uma perspectiva inicial de crescimento, o Brasil teve que dar um salto de fé para se readaptar às condições estabelecidas. De acordo com o método de ensino, a aprendizagem mediada pela tecnologia ganhou ênfase e abre espaço para interações humanas diferenciadas. Essas práticas de ensino já existiam, mas alcançavam pequena escala. A tecnologia teve que reformular seus hábitos para atender à demanda e às novas exigências de saúde. Este artigo apresenta e discute as perspectivas brasileiras sobre os desafios e oportunidades do uso de novas tecnologias e readaptação para a evolução e sobrevivência da pandemia. Os principais resultados sugerem que a implementação de políticas de inclusão digital visando reduzir as desigualdades regionais de acesso à internet é uma condição necessária para que qualquer estratégia de ensino online floresça e que a inovação tecnológica é paralela à progressão temporal da condição mundial.
\end{abstract}

Palavras-chave: Evolução; Acesso à internet; Tecnologia de readaptação; Inovação tecnológica.

\section{Introduction}

From the dawn of time to the sparks of the logic to the continuous creative thinking that roams our daily lives, technology has proven to be an essential component in our time span. Since its birth, researchers have speculated on the behavioral growth across the years taking into consideration factors that may influence it, including the current economic conditions that revolve around it, the social aspects that provides for users, the feedback from the population as their needs and desires ever so changes, etc. Providing all these variables, it has been concluded that the pandemic era of the COVID-19 virus has proven to be of major drastic change and influencer on the technological growth. To further understand how the impact of the pandemic generated a new behavior for the evolutionary growth of what has become a crucial existing part of our daily lives, we must first analyze the conditions pre-existing that surrounded ourselves to later compare the re-adaptation that was forced upon all. 


\section{Pre-Pandemic Tech View}

In a general perspective of the overwhelming speed which technology has developed, author of the Hosting Tribunal Nick Galov uses Moore's Law, a prediction created by American engineer Gordon Moore in 1965, to exemplify this large advancement. Figure 1 shows the progressive behavior that Moore's Law predicted not only for next decade but for more than 50 years (Galov, 2021). An analysis of these conditions leads to speculations that provide insight into large technological growth, such as [by 2025] the almost 40 billion smart devices expected to be connected and interacting with data through the Internet, the nearly $\$ 80$ billion market for web hosting services, and the concentration of the majority of technological investment on cloud solutions (Galov, 2011).

To provide supporting ground for these statements, quantitative measurements of the world's startups, which total to 1.35 million tech startups, and the revolutionizing Global AI market, which has pushed technology innovation to new boundaries, is expected to reach upwards of $\$ 89$ billion are primary factors to conclude that withing the expansion of time and groundbreaking internet usage (which has surpassed the 4 billion margin, according to We are Social), technology has not only increased its' growing pace but also has not shown any sign of contracting. In addition, author Max Rosser provides further statistics that reinforce Moore's law and technology advancement when discussing the growth of integrated circuits (ICs), where "every 18 or so months, computer processing speed doubles. The number of transistors that fit into a microprocessor reached over 10 billion in 2017. It was under 10,000 in 1971" (Roser, 2020). This extensive margin is one of the biggest arguments for the revolutionizing growth in the tech field.

Figure 1. Moore's Law - The number of transistors doubles every 18 months.

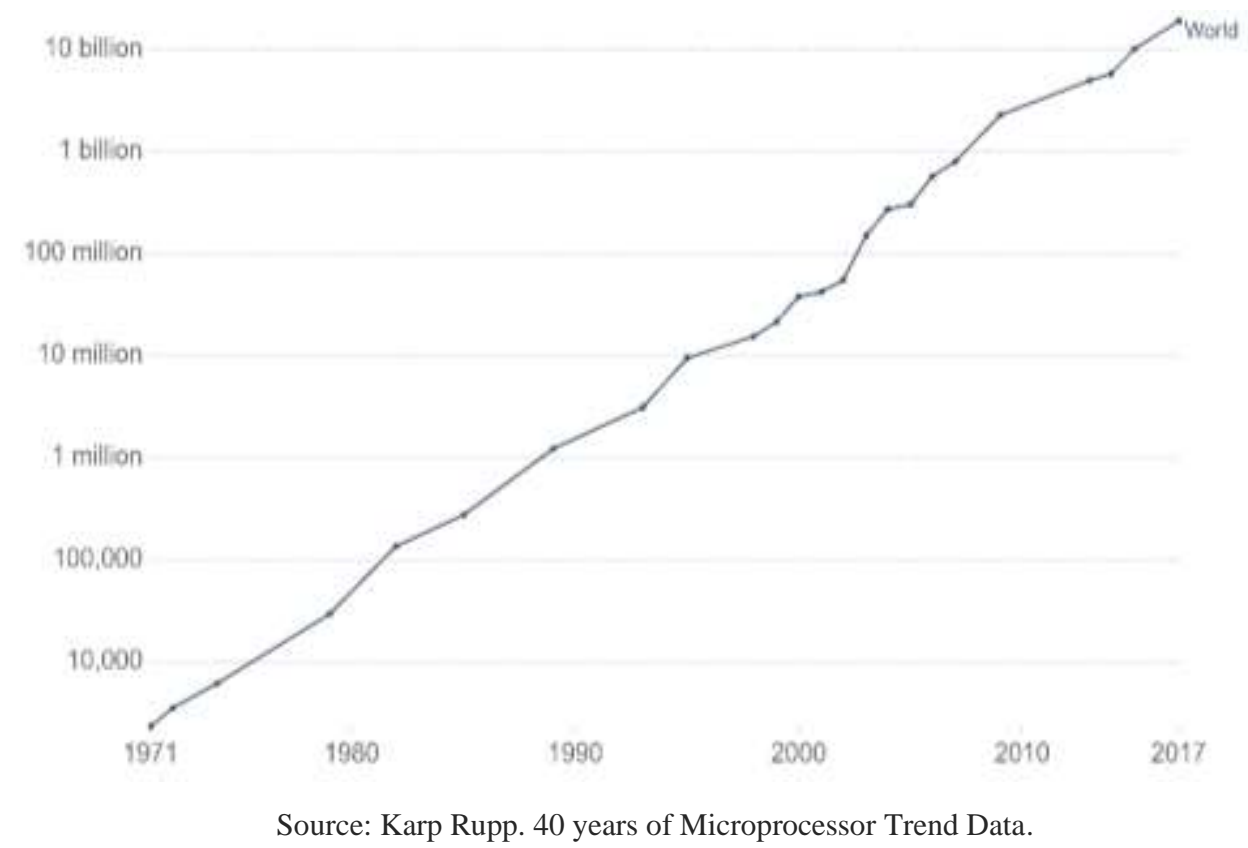

A similar growth is noted in the few years prior to the pandemic (2017-2019) amongst Tech Startups, Streaming Services, Application Programing Services (APIs) and overall Data Usage. With over 18,000 APIs in the early 2017, a growth of over 3,000 from the previous year, software companies had an average revenue of \$103 million in 2018 resulting in a 55\% increase since 2017 and an outstanding 1.35 million tech startups in early 2020.

Likewise, the Brazilian Information Technologies (IT) market grew approximately $9.8 \%$ in 2018, attaining a revenue of $\$ 47$ billion, surpassing a prior projection of $4.1 \%$, and it continued to grow in 2019 , according to a study by the International 
Data Corporation (IDC) in partnership with the Brazilian Software Association (ABES). Moreover, the electronics device market is expected to represent $38 \%$ of all IT investments in Brazil, reaching $\$ 24.5$ billion, due to sales of higher valued devices. In the early stages of 2019, the expected growth of IT investments in Brazil was of $10.5 \%$ while the global average was estimated at only $4.9 \%$ (as stated by the government agency Select USA).

According to the largest research organization in the country, IBGE - Brazilian Institute of Geographie and Statistics, the use of technology with internet access since 2018 has been cell phones and microcomputers. However, the public education system has faced several obstacles like how to match private education, which has been the best choice for the Brazilian society. The social isolation arising from COVID-19 has not only provided the opportunity to discuss the means of providing technologies, such as 5G internet and tablets, for students and the youth. The compulsory chain of solidarity imposed technological standards that the country was not prepared for, such as Internet access for instructors in rural areas and the use of virtual classrooms, and provoked estrangement seen as the use of mobile technologies was largely for entertainment.

A notable correlation between Brazil's population size and market capacity can be induced, since approximately onethird of Latin America's population resides within the country's territory and the country is the region's largest telecom market. Statistical analysis project that the Brazilian telecommunications services market will approach $\$ 45.76$ billion by 2022 , implying a market growth of $20.42 \%$ since 2016 based on a study by market research company Frost and Sullivan (Roser, 2013). Investment in 5G has occurred gradually within the country's evolution and has influenced its market ever so slightly.

With these considerations, Brazil's opportunity for growth is likely to only increase with the end of the current decade as 2020 was believed to have countless opportunities in the technological world. Global Managing Partner of McKinsey \& Co. Kevin Sneader expounds on this thought when stating that "at a time where disruption is impacting the world and historic trading relationships are being impacted by geopolitics and technology, Brazil stands out as a country where opportunities for growth appear compelling and there to be seized." Enhancing this ideology, Magazine Luiza's Board of Directors' Chairwoman Luiza Helena Trajano affirmed that "all indications point to 2020 being a year of gradual economic recovery. The adjustments and reforms required for economic growth are moving, such as the pension reform and Congress' efforts for a tax reform. As a result, some planned investments should start flowing in, and increased employment should drive economic growth" (Callichio, 2020).

A major opportunity that proved to be an upper hand for Brazilian technological growth was Costumer Centricity. Brazilian consumers were believed to be ready for a technology-led disruption, described as a rapid increase internet penetration and evaluated as the second highest online engagement globally. Executives reacted by utilizing technology improvements to engage their customers with the final objective of increasing LifeTime Value (LTV) (Callichio, 2020). The abundance of customer-centric startups is transforming the way consumers intermingle with companies and is setting a new standard for officeholders. This trend for customer centricity is reasonable when international companies with high customer approval scores outpace associates across multiple financial metrics is taken into consideration.

A study conducted solidifies the growing argument that, in fact, Brazilian consumers are ready for tech-based disruptions, this due to $71 \%$ of Brazilians owning a smartphone and approximately 9.5 hours are spent per user, per day, on the internet (leading as the second highest intensive internet usage globally), of which $89 \%$ is attributed to children and adolescents (Butcher, 2020). Also, of note is that these statistics vary amongst the different economic classes. As shown in the charts below, after collecting data from the usage of the most common forms of devices with which internet access of available and possible, there is a clear distinction of the reach that each economic class has. This provides a better understanding of the impact that technology innovation has on LTV and customer satisfaction and feedback, since the new advancements not only will have to suffice the demands of the population, but its growth will only be capable of proliferating if social and economic inclusion is sustainable. 
Additionally, Brazil have also built up an enormous powerhouse when it comes to the engineering tech pool in the world. Having a technological talent pool that is continuously growing and being filled with distinctive students every year by recognized research institutions has helped create new technologies, and Brazil has, to this day, one of the most competitive tech pool cost. Figure 2 provides insight of Brazil's standing amongst the top countries when measured through the annual compensation for Data Scientists (USD). These conditions favor Brazil's growth due to the adequate structure to quicken and produce distinctive innovation. Ranked with the highest tech pool, the capacity for newer innovations and more accessible forms of development in the field becomes reachable and a more realistic goal as researchers and scientists work nationally to update on improvements and sophistication. The most notable argument for it is the presence of over 40 innovation parks, the incubation of more than 120 startups and an outstanding value in corporate research and development that surpasses USD 1.3 bn.

\section{Graphic 1.}

\section{ELECTRONIC DEVICES FOR INTERNET USAGE PER ECONOMIC CLASS \\ - \% AMONG CHILDREN AND TEENAGERS BETWEEN 9 AND 17 YEARS OF AGE -}

$\square$ High Class $\quad$ Mid Class $\quad$ LLower Class

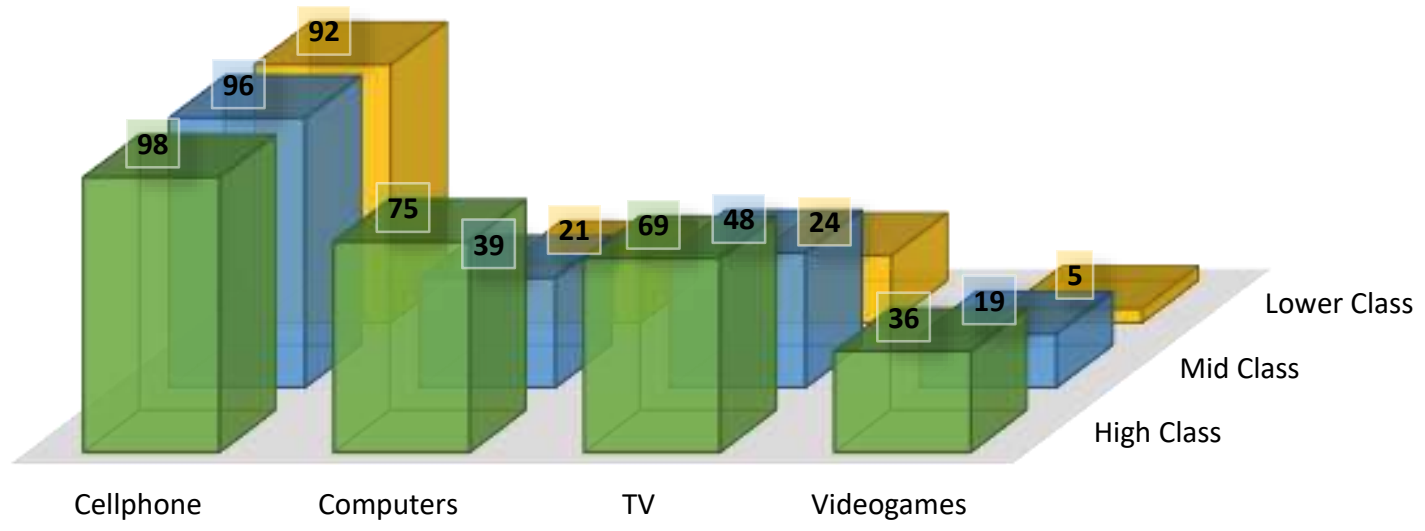

Source: CGI.BR/NIC.BR. Regional Center for Informational Society Development and Studies (Cetic.br)/IBGE. 
Figure 2. Brazil's ranking among the nations' highest engineering and tech pool.

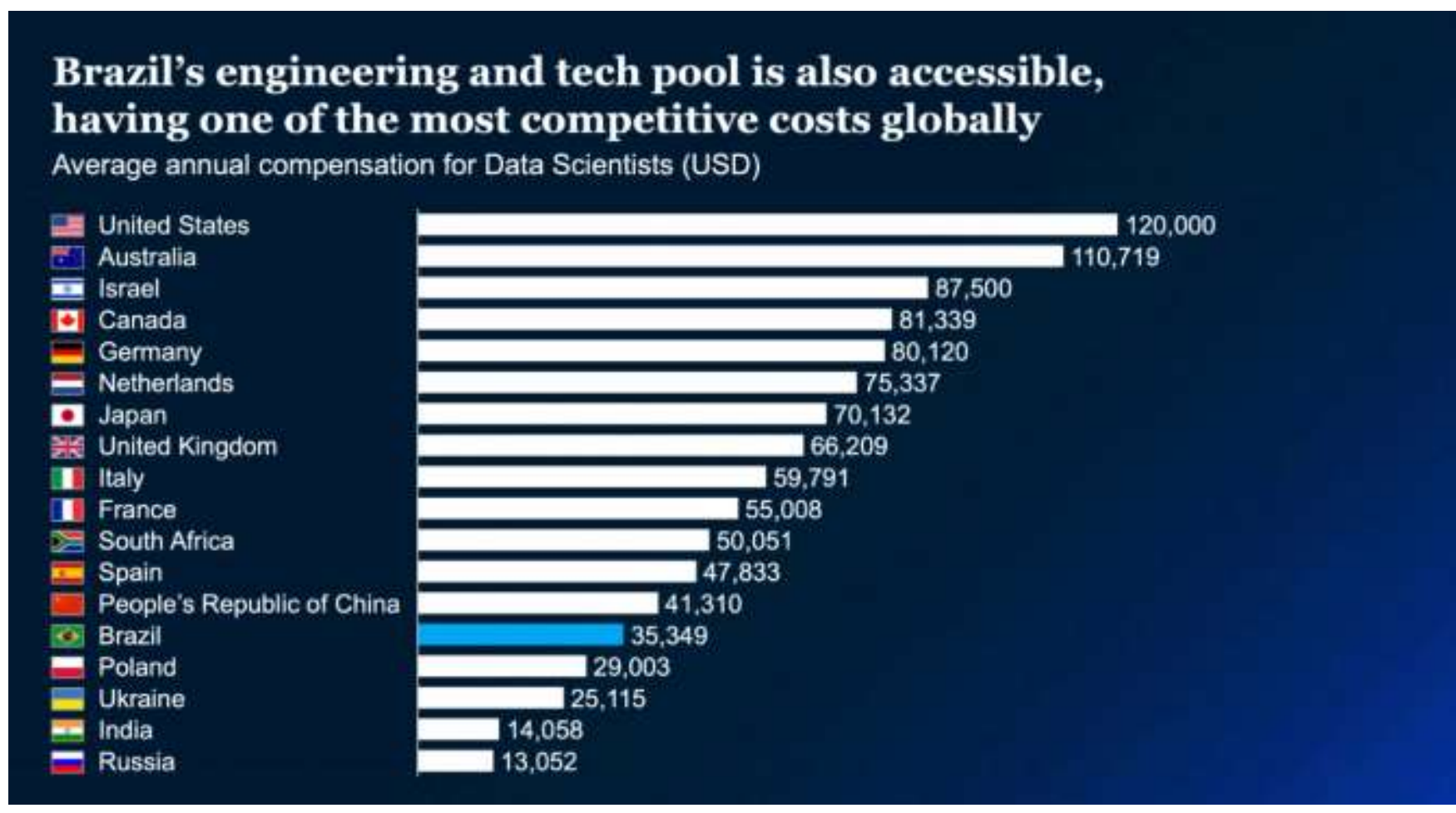

Source: “Governments that serve” Interamerican Development Bank, (2016).

\section{Digital \& Analytics Global leader}

\section{McKinsey \& Company}

"Brazil is a true leader in the tech space: a buzz with innovative startups, ahead in mobility, and a test bed for the big global tech players. At a time when others are navigating the challenges of tech disruption, Brazil is out in front capturing the opportunities." The quote of Kate Smaje (2016) just followed is a greater example of another stepping stool for Brazil in the topic technology innovation and investment. To further identify this capture of opportunity is none other than informal and distance learning (EAD) which has transformed the Educational field in the country. As a primary condition, the Private Education system stands as an important role in Higher Education in Brazil, representing close to 83\% of enrolled students and thus leading amongst the world's top Private Higher Education systems. Online non-regulated \& Informal courses have become increasingly important as learning tools, especially among web-based identities and so the aim of 21 st century skills for students is shifting from the use of core skills to character traits and creativity. Distance Learning is a growth factor of higher education in Brazil, representing 40\% of students in 2018, with an Undergraduate Academic Control (CAGR1) of approximately 20\% per year (Colliachi, 2020).

Brazil's new generation (Gen Z) bring new values that have become a source of inspiration. The first generation of "true digital natives": from earliest youth, they have been exposed to internet, social networks, and mobile systems (such as shown in Figure 3). As a result, Gen Zers (as they are more popularly identified as) are hypercognitive and extremely comfortable with storing and cross-referencing many sources of information at a single time. 
Figure 3: Mobile systems for internet and social networks that revolve the new generation.

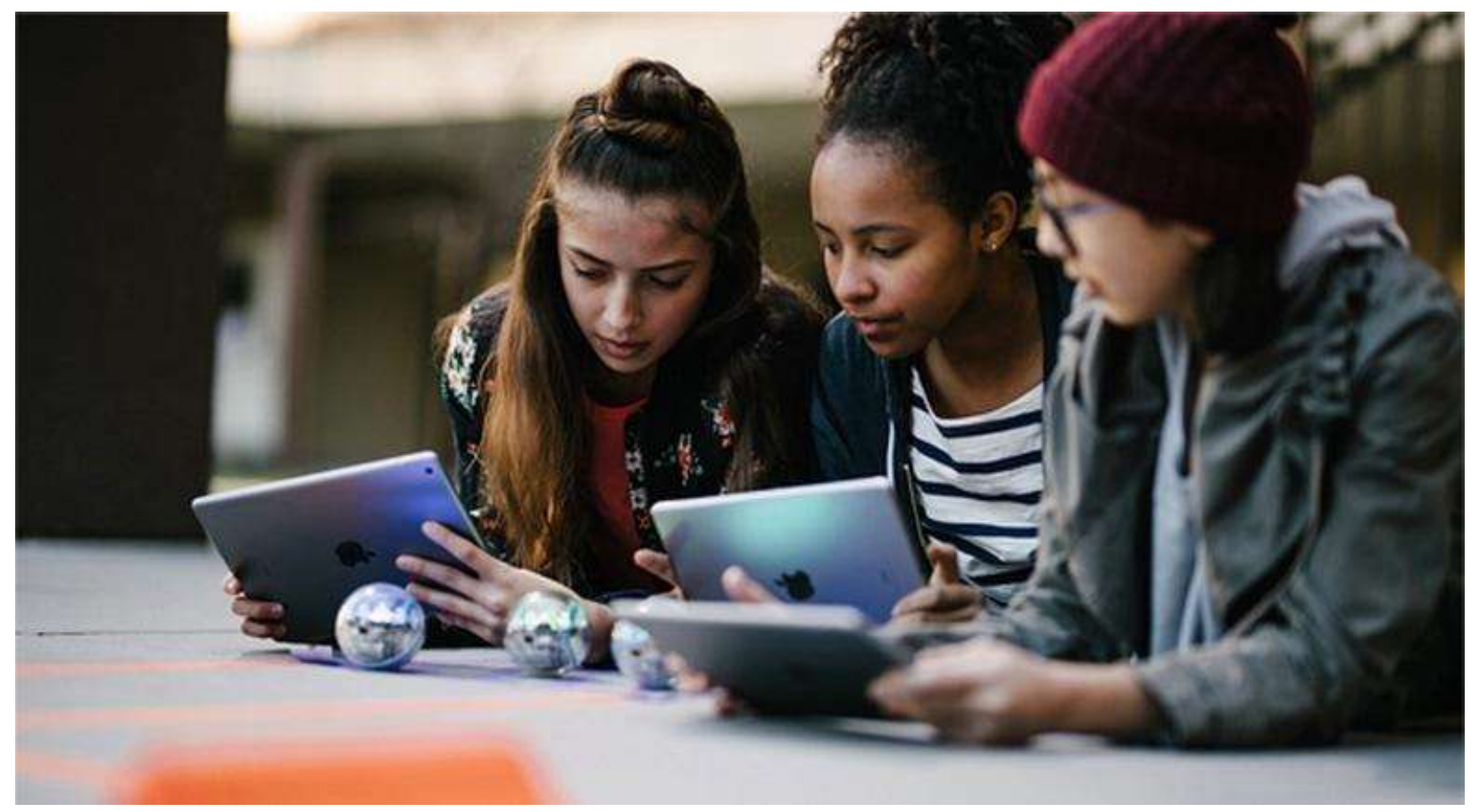

Source: Apple \&Co (2020).

The Pandemic

As the pandemic grew in the early 2020, neighborhoods, cities, states, regions began closing. The fear of being infected surrounded every civilian as they woke up each day that passed and to increase the tension amongst the population and their political representatives, the commerce slowed. With lesser physical activity within the street market, the supply and demand aspect took what was one of the biggest and most drastic impact in years. Whether the clientele was absent, or the providers were, economist and researchers foresaw a dark time to come. Institutions and markets would be closed for an indefinite time without a clear solution to the now present situation of the country and across the nation, the technological sector feared what this would then result.

For this, digital adoption had to take a quantum leap in both organizational and industry levels. During the pandemic, consumers have moved dramatically towards online channels, and companies and industries had to respond in turn. Those responses tended to answer most of the health demands for tech innovations and aid for patients and medical staff.

Such example of response that become a large innovative advancement in health technology was the development of a mechanical ventilation monitoring system using electrical impedance tomography (EIT). Developed by Timpel, a startup based in the metropolitan city of São Paulo, Brazil, this system is being used in numerous countries to provide intensive care for patients under more critical conditions of COVID-19. This innovation was formed with support from FAPESP via its Innovative Research in Small Business (PIPE) Program, the system provides vital real-time information for medical teams at the bedside to monitor the patient's lungs uninterruptedly and noninvasively. This optimizes mechanical ventilation, reducing the amount of time during which patients depend on the machine to breathe and minimizing the adverse side effects of intubation (Azevedo, 2020).

In this venture, A non tradition project was supported by funding proposals issued by PIPE-FAPESP in partnership with FINEP- Brazilian government's innovation agency, to foster the development of products, services or processes by tech startups and small businesses in the state of São Paulo to combat COVID-19. Through the project supported by PIPE-FAPESP, the researchers now plan to simplify the onboard software to reduce the cost of the machine and to enable medical teams to 
operate the system remotely so they can avoid having to circulate a great deal in ICUs. "This will also allow the staff of reference hospitals to assist hospitals located in places distant from major cities and with scant human resources,” (Alison, 2020).

Belts and electrodes that meet the patient's skin will be disposable, in contrast with those extensively used in tomography. "The device will be configured to run on battery power, which could be crucial during patient transfer and in remote areas of Brazil," Holzhacker (2020). Another innovation, he added, will be the development of an entirely novel application for use in monitoring mechanical ventilation that will be programmed to recognize the clinical characteristics that are being observed in cases of COVID-19.

Another factor that requested attention as an innovative method to confront the pandemic was the conditions present for education accessibility. Wilder-Smith and Freedman (2020) state that "social distancing and quarantine are designed to reduce, restrict circulation and interactions between people. This distancing lays the foundation for strengthening technologybased learning. Innovative applications will enable new paradigms to produce knowledge using digital tools and non-presential social interactions. Since the educational spaces are closed, there is an open demand for learning. This theme occupies space in educational discussions today, and the obvious output is the Internet and the equipment connected to it. However, the debate is not limited to the means but advances to the issues of curriculum and the need to change the behavior of teachers, institutions, and students. In this sense, Almeida, and Valente (2012) observe that the adaptation of technologies to pedagogical plans is constituted, but that media, involve information, cultural relations, languages, times, and spaces. These approaches generally present communication technologies as tools that innovate educational practices, since they allow greater flexibility in learning methods (Andrade, 2019).

\section{Methodology}

All methodological action comprises experimental research, whether the researcher been the ex-post participant research or the action research been a case study and field research. Documentary and bibliographic research have similarities, differing from each other in the nature of the sources. The researcher who opts for documentary will seek information from the bodies themselves, whether public or private. Such research involves written materials, such as laws, letters, biographies, newspapers, etc. (Ludke; Marl, 1986), and also unwritten materials, such as "photographs, recordings, television, radio, drawings, paintings, songs, clothing, art objects, folklore, etc." (Lakatos; Marconi, 2001, p. 43). Other sources are descriptions.These documents can constitute important sources, and from these evidences can be extracted that substantiate strong statements and statements for the research (Ludke; Marli, 1986). In the bibliographical research, the researcher makes a survey of all the content, with a scientific basis, already published and related to the problem in focus.

Among the materials consulted are books, encyclopedia entries, magazines, conference papers, separate publications and theses (Macedo, 1994; Lakatos; Marconi, 2001). For Macedo (1994) apud Vilela 2009, bibliographical research is divided into a restricted concept and placed an abroad concept. In the restricted concept, the researcher selects documents that are deeply related to his research problem and records the references used. In the broad concept, bibliographic research is understood as the total initial plan of any work. In this, numerous methodological procedures are involved, divided into stages such as: identification and location of documents for research; preparation of themes and sub-themes of the work (as a form of organization); listing and summary of the material read, among others.

Particularly in this paper, it was opted for an explanatory research with data analyses. Generally, explanatory research is a continuation of descriptive research that other researchers did. According to Vilela (2009) apud Journal of Scientific Initiation of the FFC, v.9, n.3, p. 285-292, 2009, the good is "have under controlled conditions and known by the investigator, to observe the results that the variable produces in the object" 


\section{Results and Discussion}

The World Health Organization recommended the closure of educational institutions to contain the advance of the new coronavirus and as part of a package of isolation and social distancing measures. In this sense, researchers Reimers and Schleicher (2020), have developed a work to guide and develop education strategies for the closure of educational institutions. For these authors, schools around the world are changing education models to alternative forms of delivery, including virtual platforms, to meet the physical distancing requirements of the COVID-19 pandemic. Educators are navigating in unknown territory, and students may be facing the consequences of lost learning time.

The work developed by Reimers and Schleicher (2020) had the participation of the Global Education Innovation Initiative Harvard Graduate School of Education and the Directorate of Education and Skills of the OECD, which aims to collaborate with educational measures to develop and implement effective responses to education in the period of social withdrawal caused by the COVID-19 pandemic. The work suggests that managers of educational institutions improve their plans for the continuity of education through alternative modalities during the period of social isolation. In this sense, technologymediated education becomes an essential model, because it works with the availability of content on the Internet and with the possibility of synchronous and asynchronous interaction with teachers and students of the same group.

In the sense of health adaptations, immensely important is the command of the methodologies employed in the global health field, expanding the capacity of Brazilian researchers to participate in dialogue with the field's international literature, both to question it and to join the critical schools that have emerged around the world, especially in the developing countries. From the point of view of international academic cooperation, the initiatives in South America and the Global South should be prioritized. Promising methodological paths can be explored, such as studies on the circulation, dissemination, and global transfer of public policies. Methodological training to conduct case studies and the improvement of comparative case study methodologies are also highly relevant.

\section{Conclusion}

Facing probably one of the most draconian crises, Brazil made a deep decision to move forward with education based in tech support. The country plays an important role in South America in the recent decades whether as a commodities leader or high tech developer. The year of 2020 implemented in the whole country a spirit of research associated to the education and bioengineering. Mostly in the poorest regions, a critical vision in global health policy, "free assistance for all" was see as an open futuristic vision, which came with a distinguish and qualified hand of professionals. Brazil move in direction to a grande scenario of credibility in education and science. In this regard, it is even more important for researchers in the global health field to be alert to the themes in which Brazil's new international action has the most intense repercussions, such as issues related to democracy and human rights, and within these, especially gender and economic issues. Challenging the Northern Hemisphere's predominance in the global health research agenda and incorporating sustainability as a reference capable of backing a critical view of the cycles of interest dedicated to the field, Brazilian researchers can both confront the automatic importation of standardizing research output tied to the developed world's interests and contribute to the consolidation of global health approaches in which people and the environment truly take first place.

\section{References}

Elton, A., \& Geraque, E, (2020) "Brazilian Technology Is Used in Several Countries to Treat COVID-19 Patients." AGÊNCIA FAPESP, Agência FAPESP, 2 agencia.fapesp.br/brazilian-technology-is-used-in-several-countries-to-treat-covid-19-patients/33986. 
Leonardo, A. C. et al. (2020) View of Use of Technologies in Brazilian Public Higher Education in Times of Pandemic COVID-19, RSD Journal, 4 July 2020, rsdjournal.org/index.php/rsd/article/view/5485/4797.

Azevedo, A. (2020) IBGE - Educa: Jovens.” IBGE Educa Jovens, Instituto Brasileiro De Geografia e Estatistica, educa.ibge.gov.br/jovens/materiasespeciais/20787-uso-de-internet-televisao-e-celular-no-brasil.html.

Brazil - ICT (2019) - Informations and Communications TechnologiesBrazil - ICT.” Brazil - ICT - Informations and Communications Technologies | Selec tUSA.gov, www.selectusa.gov/article?id=Brazil-Information-Communications-Technologies

Butcher, I. et al. (2020) "89\% Das Crianças e Dos Adolescentes Brasileiros São Usuários De Internet." TELETIME News, TELETIME, teletime.com.br/23/06/2020/89-das-criancas-e-dos-adolescentes-

Calicchio, N. et al. (2020) “Brazil 2020 Opportunity Tree.” McKinsey \& Company.

Galov, N. (2021) "How Fast Is Technology Growing - Moore's Law Can't Keep Up.” HostingTribunal, 15 Jan. 2021 (ABES). hostingtribunal.com/blog/howfast-is-technology-growing/\#gref.

Gil, A. C. Métodos e técnicas na pesquisa social. (5a ed.), Atlas, 1999.

Macedo, N. D. Iniciação à pesquisa bibliográfica: guia do estudante para a fundamentação do trabalho de pesquisa. (2a ed.), Loyola, 1994.

May, T. Pesquisa social: questões, métodos e processos. Tradução de Carlos Alberto Silveira Netto Soares. (3a ed.), Artmed, 2004.

McKinsey \& Company - (2020) How COVID-19 Has Pushed Companies over the Technology Tipping Point--and Transformed Business Forever.” McKinsey \& Company.

Reimers, F. M., \& Schleicher, A. (2020) -Toward a Global Response to COVID-19. A framework to guide education strategies amid school closures in countries around the world. https://www.gse.harvard.edu/news/uk/20/04/toward-global-response-covid-19.

Roser, M., \& Hannah, R. (2013) “Technological Progress.” Our World in Data, Our World in Data,

Sousa, Thais, (2020) "Brazil Invests in Technology Development." Agência De Notícias Brasil-Árabe, ANBA - Brazil-Arab News Agency, anba.com.br/en/brazil-invests-in-technology-development.

Ventura, Deisy de Freitas Lima, et al. (2020) "Challenges of the COVID-19 Pandemic: for a Brazilian Research Agenda in Global Health and Sustainability." Cadernos De Saúde Pública, Escola Nacional De Saúde Pública, Fundação Oswaldo Cruz, www.scielo.br/scielo.php?script=sci_arttext\&pid=S0102311X2020000400502\&lng=en\&nrm=iso\&tlng=en.

Vilela, F. (2009) et al. Tipos de Pesquisas: enfoque na educação especial in Revista de Iniciação Cinetífica da FFC, 2, $285-292$.

Wilder-Smith, A., \& Freedman, D. O. (2020). Isolation, quarantine, social distancing and community containment: pivotal role for old -style public health measures in the coronavirus (2019-nCoV) outbreak. Journal of travel medicine, 27 (2). 